\title{
QUESTIONING LIBERAL ISLAM IN INDONESIA: Response and Critique to Jaringan Islam Liberal
}

\section{Ahmad Bunyan Wahib}

Lecturer at the Faculty of Islamic Law, State Islamic University Sunan Kalijaga Yogyakarta.

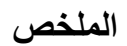

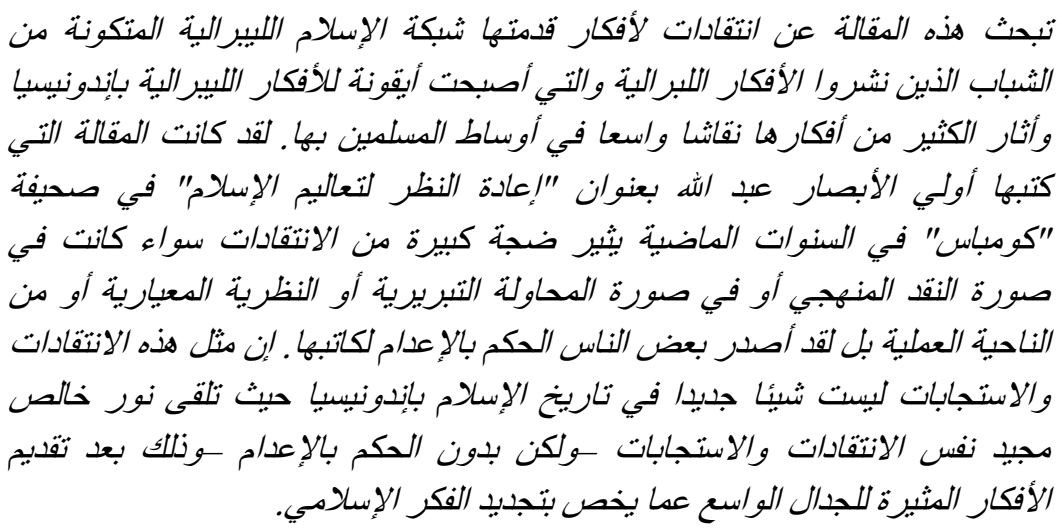

\section{Abstrak}

Tulisan ini membahas tentang respons terbadap pemikiran yang dilontarkan oleh para pendukung Jaringan Islam Liberal (IIL), sebuah jaringan yang beranggotakan anak-anak muda yang menyebarkan gagasangagasan pemikiran liberal. JIL telah menjadi salah satu ikon pemikiran Islam liberal di Indonesia. Banyak di antara gagasan-gagasan pemikiran yang diusung oleh para anggotanya menjadi gagasan yang kontroversial. Sebuah artikel berjudul "Menyegarkan Kembali Pemahaman Islam" yang ditulis oleh Ulil Abshar-Abdalla dan dimuat dalam harian Kompas menjadi salah satu artikel yang paling kontroversial. Berbagai respons dan kritik telah dilontarkan terhadap artikel tersebut, baik respons 
metodologis kritis ataupun apologetis, respons yang bersifat teoretis normatif maupun praktis. Bahkan fatwa mati telah dikeluarkan oleh sekelompok orang bagi penulis artikel tersebut. Dalam banyak hal, respons dan kritik. tersebut bukanlah hal baru dalam sejarah perjalanan Islam di Indonesia. Berbagai kritik serupa juga telah dilontarkan oleh berbagai kalangan terbadap Nurcholish Madjid di era 1970-an ketika melontarkan gagasan yang sangat kontroversial, yaitu gagasan tentang pembaharuan pemikiran Islam. Hanya fatwa mati saja yang tidak pernah keluar bagi Nurcholish Madjid.

Keywords: Islam Liberal, Jaringan Islam Liberal(JIL), Renewal of Islamic Thought (Pembaharuan Pemikiran Islam).

\section{A. Introduction}

This article deals with the development of liberal Islam in Indonesia by concentrating on the group Jaringan Islam Liberal (Liberal Islam Network; henceforward JIL). ${ }^{1}$ The members of this group claim that they are proponents of liberal Islam. The term of liberal Islam refers to a trend among a particular group of Muslims who argue that understanding the text of Islamic teachings should be complemented by the context in which it is being reinterpreted because the text does not exhaust all the meanings of the revelation. ${ }^{2}$ The term also stands for an attitude that is essentially tolerant, allowing diversity in those areas which are often traditionally held to be fundamental. ${ }^{3}$ It also refers to an interpretation of Islamic teachings which is concerned with such issues as democracy, separating religion from political involvement, women's rights, freedom of thought, and promotion of human progress. ${ }^{4}$ In short, it can be said that the term liberal Islam refers to the understanding of Islamic teachings through searching the essential meaning of the texts and by utilizing the fruits of modernity.

${ }^{1}$ See www.islamlib.com/arsip/diskusi.php, accessed on 16 November 2002.

${ }^{2}$ Ibid., p. 4.

${ }^{3}$ Leonard Binder, Islamic Liberalism: A Critique of Development Ideologies, (Chicago: University of Chicago Press, 1988), pp. 2- 4.

${ }^{4}$ Ibid., pp. 13-18. 
Referring to various prominent Muslim scholars with similar ideas, ${ }^{5}$ this group spreads basic ideas such as the opening of the gates of ijtihàd, stressing the spirit of religious ethics, pluralism and relativism, the support of minorities, freedom of religious expression or religious freedom, and secularisation (the separation of religion and politics).

It is interesting to study JIL because this group has aroused many responses to the ideas which it promotes, even the death penalty has been passed by Forum Ulama Umat Islam (Forum for Muslim Scholars of Muslim Society) on Ulil Abshar-Abdalla, the coordinator of JIL, because of the ideas expressed in one of his articles.

Besides the responses of fundamentalist Muslims, many other responses have been directed towards JIL. These responses reached a peak when Ulil Abshar-Abdalla wrote an article entitled "Menyegarkan Kembali Pemahaman Islam" (Freshening up the Understanding of Islam) published in the daily newspaper Kompas, ${ }^{6}$ in which he threw some controversial statements into the ring such as non-literal interpretation, differentiation between particular and universal values in Islam, inclusiveness of Muslim society and critically understanding the Prophet as a historical person. ${ }^{7}$ An edited volume, Islam Liberal \& Fundamental was compiled of responses which were classified as either pro or anti Ulil's article.

Islam Liberal \& Fundamental consists of the compilation of the responses to the ideas. Islam Liberal \& Fundamental unequivocally reveals that some Muslims argue that JIL exerts a positive influence on Islam

${ }^{5}$ Many Muslim scholars across the Muslim world such as Azyumardi Azra, Nurcholish Madjid, Masdar F. Mas'udi, Mohammad Shahrour, Ahmed an-Na'im, Farid Essack, Hassan Hanafi and Mohammed Arkoun have significantly influenced the formation of JIL. In its website, JIL call them kontributor (contributors) of Jaringan Islam Liberal. See www.islamlib.com/contributor.php, accessed on 16 November 2002.

${ }^{6}$ Ulil Abshar-Abdalla, "Menyegarkan Kembali Pemahaman Islam,” Kompas, 18 November 2002.

${ }^{7}$ This is based on the responses devoted to JIL from its formation to the end of 2003 (around 30 months). A book entitled Islam Liberal \& Fundamental, Sebuab Pertarungan Wacana consists of more than 40 articles devoted to Ulil Abshar-Abdalla's controversial article. "Menyegarkan Kembali Pemahaman Islam" by Ulil Abshar-Abdalla Kompas, 18 November 2002. See also Ulil Abshar-Abdalla et al., Islam Liberal \& Fundamental, Sebuah Pertarungan Wacana, (Yogyakarta: eLSAQ, 2003). 
which supports the ideas of Islam as a tolerant religion supporting peace and that it is in line with modernity. Other Muslims indicate that although the ideas of liberal Islam have positive effects on the development of Islam in Indonesia, caution needs to be exercised if the ideas are not balanced in their approach to understanding Islam. The rest argue that liberal Islam does not have any authoritative normative references in Islamic doctrine. They argue that JIL is no more than a representation of the inferiority of Muslims before the West. Media Dakwah, as has been quoted by Akh. Muzakki, even stigmatizes JIL as a terror to Muslims, a "diabolical logic" (logika iblis), a threat to Islam, a deviant sect, an agent of Orientalists and Secularists, and finally a group of Muslims who oppose to dialogue. ${ }^{8}$

This article is a bibliographical study. In this study, these responses will be analyzed from the book as well as some articles devoted to criticizing liberal Islam. Because so many responses have been evoked in response to JIL, this study will concentrate on the responses particularly directed towards the article "Menyegarkan Kembali Pemahaman Islam by Ulil Abshar Abdalla," as more than thirty articles have been written in response to his ideas. This is based on the argument that the responses are representative enough to describe the variety of opinions about liberal Islam. Additionally, in order to strengthen the analysis, some books devoted to liberal Islam in Indonesia also will be discussed.

\section{B. "Menyegarkan Kembali Pemahaman Islam": A Controversial Article}

In this article, Ulil Abshar-Abdalla (Ulil) proposes some controversial ideas. First of all he argues that Islam should be looked at as a living organism (organisme yang bidup) which has evolved in line with the development of civilization. Ulil is convinced that in order to reach a proper understanding on the development of civilization, a critical understanding of Islamic teachings should be reached through looking for the essential meaning of the text. By doing this, particular or local values, such as the penalty of cutting off a hand or wearing a

\footnotetext{
${ }^{8}$ See Akh. Muzakki, “Perseteruan Dua Kutub,” p. 43.
} 
veil, and universal ones, such as justice and equality within Islamic teachings can be attested. ${ }^{9}$

In addition, Ulil emphasizes that Muslims should have an inclusive outlook regarding inter-religious and cultural relationships. Muslim society is, he argues, a part of the entire world community unified by humanism. In this context, all ideas opposed to humanism such as doctrines forbidding inter-religious marriage have to be repudiated.

He also proposes the idea of secularization. Muslims need a social order which draws a distinct line between religion and politics. He believes that religion is a private affair which should be managed at a private level, and politics is public affair which is managed by social consensus. ${ }^{10}$

On the law of God, Ulil believes that there is no law of God in the sense in which most Muslims understand this concept, such as family law and cutting off the hand of a thief. What should be believed in are universal principles such as the five fundamental elements of classical Islamic legal reasoning (usül al-khamsa) which are well known as maqușid al-shari' $a$. They included the protection of freedom of religion, reason, property, family and honour of human beings.

On the position of the Prophet Muhammad in the context of history of Muslim society, he argues that Muhammad was a man who needs to be critically analyzed. Muhammad, like all people, was fallible.

${ }^{9}$ In one discussion, through the mailing list http:// www.islamliberal.yahoogroups.com on Islamic liberalism, Ulil emphasizes the historicity of the text. Although he is aware that this view has some weaknesses, such as the limit of the knowledge of the context of the text itself, he believes that texts, including the Qur'an and the Hadith, cannot be separated from the context within which they occure. Interview with Ulil Abshar-Abdalla on liberalism and fundamentalism, Thursday, 28 August 2003.

${ }^{10} \mathrm{On}$ one occasion he even argued that the secular state is better than the religious state, including the Islamic state, because a secular state can manage positive and negative energy at the same time. This competence lies beyond the scope of the religious state because the religious state rejects negative energy. See Anonymous, "Islam Liberal Versus Islam Literal," Tempo, No. 38/XXX(19-25 November 2001), p. 96. This is also available at http://www.islamlib.com/BERITA/tempo.html, accessed on 17 December 2002. 
In this context, Muslims society in Medina at the period of the Prophet should be understood as a successful effort of the Prophet to build an ideal society in a particular time and place. Islam in the period of the Prophet is a result of an attempt to actualize universal values in a particular context. Therefore, Muslims do not need to follow the Prophet literally because this sort of unthinking behavior will reject the universal values of Islam. Muslims should embrace ijtibäd in order to actualize, to the best of their abilities, Islamic teachings in accordance with the context. In this, the ideology of plurality plays a significant role because it is an ideology that accepts diversity among Muslims themselves and among other groups.

At the end of his article, Ulil argues that religion exists to ensure human goodness, and that a human is a living organism who develops in quality and quantity. Because of this, religion should have the ability to develop itself in order to solve the many different, ever changing problems faced by people. If Islam, as a religion, is interpreted in a way which is contradictory to general interest (maslaha 'amma), or even oppresses humanity, then, it is useless to human beings.

\section{Responses Pro and Against the Article}

As soon as this article was published, numerous responses were written, which will be elucidated upon in this section. I will not concentrate on the degree to which they support or deny the idea of liberal Islam, but rather view them from the degree of criticism to Ulil's methodology, to his materials, and to the way of propagating liberal Islam. Based on this framework, there are, at least, three forms of response. The first is a response to the mode of thought or methodology of JIL. The second is a response to the matters which JIL promotes or an apologetic response. The third is a response to the modes of communication by which the members of JIL disseminate their ideas to their audience. This response is classified as a technical response.

\section{1) Methodological Critical Responses}

Several people criticized Ulil's methodology and epistemology. These include: Haidar Bagir in two articles entitled "Islib Butuh 
Methodology"(Liberal Islam Needs a Methodology)" and "Beberapa Pertanyaan Untuk Ulil Abshar-Abdalla" (Some Questions to Ulil Abshar-Abdalla), ${ }^{12}$ Husni Mu'adz in "Komentar Serius Untuk Ulil Abshar-Abdalla (A Serious Commentary to Ulil Abshar-Abdalla), ${ }^{13}$ Ahmad Gaus AF in "How Liberal Can You Go?", ${ }^{4}$ and Umaruddin Masdar in his Agama Kolonial, Colonial Mindset dalam Pemikiran Islam Liberal (Colonial Religion: Colonial Mindset in Liberal Islamic Thought $).{ }^{15}$

In "Beberapa Pertanyaan", Haidar Bagir as indicate above, critiques the method by which Ulil Abshar-Abdalla supports his argument. Haidar Bagir claims an inadequate method is a crucial problem faced by the proponents of liberal Islam. In "Islib Butuh Methodology" he also reminds the proponents of JIL to find an adequate method in order to reach an authoritative understanding. He argues that the proponents of JIL have so far shown themselves rather povertystricken in their methods of interpretation. Unlike other ideas and movements within Islam which are complemented by adequate

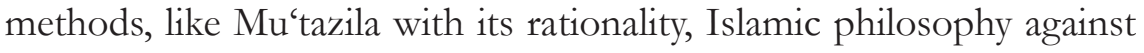
the orthodoxy upheld by Ibn Rushd, Islamic law upheld by four founders of Islamic legal school, Fazlur Rahman with his double movement, and the recent movements launched by Muhammad Arkoun, Hasan Hanafi, Abu Zaid, 'Abid al-Jabiri and so on, the proponents of JIL

${ }^{11}$ Haidar Bagir, "Islib Butuh Metodologi” Republika, Selasa 20 Maret 2002, see also http://islamlib.com/TANGGAPAN/Haidar\%Bagir\%20Republika.htm., accessed on 12 May 2003. Actually, this article was written to criticize JIL not Ulil's article.

${ }^{12}$ Haidar Bagir, "Beberapa Pertanyaan untuk Ulil Abshar-Abdalla", Kompas, 5 December 2002.

${ }^{13}$ Husni Mu'adz, "Komentar Serius untuk Ulil Abshar-Abdalla, www.media.isnet.org/islam., accessed on 7 October 2003. This article is also compiled together with other responses within Islam Liberal \& Fundamental, pp. 120-134.

${ }^{14}$ Ahmad Gaus AF, “How Liberal Can You Go?,” Kompas, 13 December 2002. This article is also available in Islam Liberal \& Fundamental, pp. 79-84.

${ }^{15}$ Umaruddin Masdar, Agama Kolonial, Colonial Mindset dalam Pemikiran Islam Liberal, (Yogyakarta: KlikR, 2003). 
have so far been deprived of this tool. ${ }^{16}$ The lack of adequate methodology leads the readers to doubt the understanding the text.

One example cited by Haidar Bagir concerns the wearing of the veil or jilbāb for Muslim women. The Qur'an explicitly states the obligation of wearing a jilbāb for Muslim women. However, Ulil argues that Muslims do not need to follow Islamic teachings which are a part of Arabic culture like the jilbāb. Rather, what Muslims do should is to follow universal values which lie beyond the text of jilbäb. Thus, Muslims should wear dress which is in conformity with public decency and which has evolved in their history. In this argument, according to Haidar Bagir, there is an impression that Ulil has understood the Qur'anic verse arbitrarily. There is no qualified reasoning proposed by Ulil in this case other than that Muslims should understand beyond the text.

A similar response was aimed at JIL by Husni Mu'adz in his "Komentar Serius" referred to earlier. In this article, he argues that the members of JIL have two failings in their propagation of liberal Islam. Firstly, they fail to formulate a universal theoretical framework by which to understand Islamic teachings, particularly those relating to the social system which they idealize. Rather their ideas are framed by ad hoc methods within which they interpret the text. The consequence of this is that interpretation is valid only for a specific case. This causes the failure of JIL to develop a framework in praxis because there is no unequivocal ideal system as a vision.

Secondly, Husni Mu'adz claims JIL fails to inventorize all the data in the text (the Qur'an and the Sunna) as "the empirical testing ground" 17 of the idealized target by which the idea of liberal Islam is

${ }^{16}$ This critique was responded to by Hamid Basyaib, a JIL activist, in his article entitled "Islib Butuh Methodology? (Tanggapan untuk Haidar Bagir)," Republika, 23 March 2002. In this article, Hamid Basyaib argues that as far as promoting its ideas are concerned, JIL brainstormings in formulating its methodology. The problem is in the systematization of the methodology by which JIL understands Islamic teachings.

${ }^{17}$ The term is from Husni Mu'adz. See Husni Mu'adz, "Komentar Serius," p. 126. 
formulated. ${ }^{18}$ The members of JIL do not stipulate their idealized aims - the main one of which is liberalism, which pay considerable attention to individual freedom, to Islamic teachings such as the concept of Islamic taxation (zakat), Islamic justice and so forth. As a result, there are no clear criteria of acceptability and the propagation of liberal Islam fails to reach critical and objective responses and evokes on emotional reaction from the public. ${ }^{19}$

Another critical response was offered by Ahmad Gaus AF in his article entitled "How Liberal Can You Go?" While both Haidar Bagir and Husni Mu'adz tend to doubt the methods by which JIL propagates its ideas, Ahmad Gaus looks more optimistically at their method. He argues that Islam, as well as other religions, faces a serious threat, that is, the stagnation of religious thought. This inertia in religious thought will lead to the marginality of religion in daily life because religion simply does not provide adequate solutions. He argues that this is why historically there are some groups in religious society which have tried to overcome this serious problem by promoting the idea of renewal of religious thought. Islamic Neo-Modernism promoted by Nurcholish Madjid in the 1970s and liberal Islam promoted by JIL can be put firmly into this framework. However, he, citing the statement of Salahuddin Wahid, argues that JIL is more liberal than Islamic NeoModernism. ${ }^{20}$

Furthermore, Ahmad Gaus argues that it is not an easy task to freshen up the understanding of Islamic teachings among Indonesian Muslims. A serious obstacle has to be overcome within society, as feels

${ }^{18}$ The members of JIL are more or less aware of this shortcoming. From the beginning, they have argued that the liberal Islam which they uphold does not have a fixed foundation in the text. They stress the fruits of modernity as their basis of the understanding the text.

${ }^{19}$ Husni Mu'adz "Komentar Serius", p. 130.

${ }^{20}$ In an interview with the Magazine Sabili, Salahuddin Wahid argues that JIL is more liberal than Nurcholish Madjid. This is indicated by the term by which JIL introduces the ideas. An example is the term regarding responses to the matters pertaining to the state. Nurcholish Madjid still uses the term which has religious nuance, namely masyarakat madani referring to the role of the society. In this case, JIL uses the term "civil society", a term which has originated from modernity. See Salahuddin Wahid, "JIL Lebih Liberal dari Cak Nur", Sabili No. 15 Th. IX 25 January 2002, p. 90. 
their belief has been disturbed by the movement. In this, the issues which the movement upholds and the people to whom the movement addresses its work play significant roles. According to Ahmad Gaus, the agenda which is upheld by JIL should be related to structural issues (isu-isu struktural) which are part of the major themes of modernity such as democratization and human rights. He feels that JIL should be able to put the peripheral and particular issues such as the issues of the veil (jilbab) and the penalty of cutting off the hand of a thief into the framework of structural issues. Furthermore, Ahmad Gaus argues that the issues which JIL upholds should be addressed to the entire community, not to individual members of society. In this context, social institutions such as universities, non-government organizations, including religious organizations, have strategic roles in the dissemination of the ideas. Therefore, JIL should make it a priority to promote their ideas to the institutions within society, not to individuals.

Umaruddin Masdar in his Agama Kolonial is another individual who has been spurred onto comment. ${ }^{21} \mathrm{He}$ argues that liberal Islam is heavily coloured by the imperialist paradigm which classifies religious followers into elite and ordinary followers. ${ }^{22}$ This is an idea which does not have a bearing on the reality of Indonesian society and is flawed at its epistemological foundation. ${ }^{23}$ According to him, the main characteristics of liberal Islam are a compromise between the text and the context. On the one hand, liberal Islam believes that the text identifies true moral values which can only be found through a creative interpretation of the holy text by searching the essential meaning of the text. In this case, the text has a central position. On the other hand, liberal Islam accepts the relativity of the truth in which modernity

${ }^{21}$ Umaruddin Masdar, Agama Kolonial.

${ }^{22}$ The elite followers have the authority to interpret religious doctrines and the ordinary followers should follow the interpretation of the elite. In this case, it seem that Umaruddin is inspired by Marxist theory of society without social class. He images religious society as a society without class in which all members have authority to understand the doctrines according to their understandings.

${ }^{23}$ Ibid., p. 20. This critique can be questioned. The existence of many Muslim leaders like kyai in Java, ajengan in Sunda, and tuan guru in Lombok, to mention some, are distinct proof of religious class in Indonesia. 
plays an integral role in the interpretation of the doctrines. In this context, Islam with its authentic truth can accept relative truth within modernity. This will lead to a pragmatic solution, whereby there is an adjustment of interpretation of the text to modernity through reinterpretation of the text. ${ }^{24}$

The pragmatic solution has an impact on the ways of thinking and action within liberal Islam. Liberal Islam is filled with bias of thought, of middle class values, of funding, of liberalism and colonialism. ${ }^{25} \mathrm{It}$, furthermore, becomes an imperialistic, ${ }^{26}$ and anachronistic idea because is not founded at on the basis of reality. ${ }^{27}$

Umaruddin predicts that like Islamic fundamentalism, liberal Islam will not be granted a long life. It is like a fashion which is enthusiastically responded to by Muslims in Indonesia and will disappear without any significant trace. It will be removed from Islamic discourse in Indonesia by other modes of thought. ${ }^{28}$ In the early stages of the government of the Indonesian New Order, there was a trend among Indonesian Muslim scholars to discus Islam and modernity (development). This trend was changed by the ideas of Islam and postmodernism, and Islam and civil society at the end of Indonesian New Order. At a glance, all these ideas coloured Islamic discourse. Now there is liberal Islam. According to Umaruddin, liberal Islam also will disappear without any significant results because the ideas which it upholds are external and are not grounded in the Indonesian reality. In other words, the proponents of liberal Islam are only agents as well as consumers of modernity distributed by the West. They are labourers of western ideology who will promote orders from the boss (the West). ${ }^{29}$

\section{2) Apologetic Ideological Response}

If a critical response focuses on the methodology of liberal Islam, an apologetic response concentrates on the matter and ideology of

\footnotetext{
${ }^{24}$ Ibid., pp. 18-19.

${ }^{25}$ Ibid., pp. 102-149.

${ }^{26}$ Ibid., pp. 14-27.

${ }^{27}$ Ibid., pp. 47-95.

${ }^{28}$ Ibid., pp. 41-46.

${ }^{29}$ Ibid., p. 201.
} 
liberal Islam. It is a response, whether it is a defensive or offensive, to the movement and ideas of liberal Islam which looks at the validity of liberal Islam from the perspective of an ideological and normative point of view. This response can be sub-divided into three categories: normative apologetic; critical apologetic; and practical apologetic. The first, normative apologetic is an apologetic response which criticizes the ideas of liberal Islam based mainly on normative reasoning. The main target of this critique is the validity of the idea of liberal Islam in the framework of Islamic doctrines. The second, critical apologetic is an apologetic response which concentrates on the justification or the condemnation of the ideas of liberal Islam by concentrating on the degree of conformity of the ideas in the context of Indonesian society. The third, practical apologetic, is a response which not only leads to the polemical debate, but also triggers the prosecution of physical action. While the first and the second are on the ontological and also epistemological level, the third exists on the axiological level.

\section{a. Normative apologetic response}

Hartono Ahmad Jaiz in his Bahaya Islam Liberal (The Danger of Liberal Islam), Adian Husaini and Nuim Hidayat in their Islam Liberal, Sejarah, Konsepsi, Penyimpangan, dan Jawabannya (Liberal Islam: History, Conception, Deviation and the Answer to It) can all be included as normative apologetic responses. Hartono Ahmad Jaiz (henceforward Hartono) in his Bahaya Islam Liberal attempts to criticize the doctrines of liberal Islam from a normative point of view. He tries to aim at the roots of liberal Islam which were mainly laid down in the 1970s in which people like of Harun Nasution and Nurcholish Madjid promoted the idea of Renewal of Islamic Thought. ${ }^{30}$ He condemns, more than is critical of liberal Islam. He mentions only the negative side to liberal Islam without applying any critical method as a basis for this reasoning. $\mathrm{He}$ argues that there is no valid normative argument to strengthen liberal Islam, because their ideas do not have an adequate normative foundation. He, unfortunately, does not offer any deep explanation about these statements. No critical analysis has been argued to support his idea.

\footnotetext{
${ }^{30}$ Hartono Ahmad Jaiz, Bahaya Islam Liberal, p. 9
} 
In the case of the development of liberal Islam in Indonesia, it is indelibly linked to the contributions of both Harun Nasution and Nurcholish Madjid. They are the people who are responsible for the development of liberal Islam in Indonesia. Harun Nasution promoted the idea of the rationality of Islam by adopting the ideas of $\mathrm{Mu}^{\text {'tazila }}$ which leads to the critical questioning of the fundamental doctrines of Islamic theology, including the doctrines those which have to be accepted without any question. ${ }^{31}$

From the normative perspective, Hartono argues that liberal Islam is a deviation in the understandings of Islamic doctrines. He claims there is no normative foundation for liberal Islam. Liberal Islam is a sign of Muslim weakness before the West because it accepts western ideas without any critique. ${ }^{32}$ Liberal Islam is based mainly on a method that is inadequate both from a normative and a scholarly point of view. Additionally, it does not have authoritative references. ${ }^{33}$ Furthermore, in the case of religious pluralism, Ahmad Jaiz says that liberal Islam is very dangerous because it simplifies the doctrines of Islam by claiming that all religions are equal, and that all religions teach the truth. ${ }^{34}$

Another normative apologetic response was that elicited from Adian Husaini (Adian) and Nuim Hidayat (Nuim) in their Liberal Islam. ${ }^{35}$ They concentrate on the history, including the major figures of liberal Islam, ${ }^{36}$ the mission and the threat liberal Islam poses to Islam itself, ${ }^{37}$ and the relationship between liberal Islam, the West and Zionism. ${ }^{38}$ They argue that liberal Islam is an agent of an international orientalist movement which is trying to conquer the Islamic world, putting it under domination of western thought. Liberal Islam will attract Muslims to turn away from their religion. The proponents of liberal Islam interpret

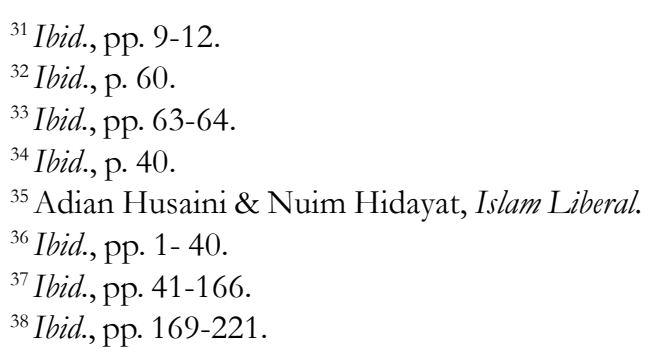


Islamic teachings in order to fulfill their own desires. ${ }^{39}$ Such an interpretation will destroy Islamic doctrines (penghancuran akidab) ${ }^{40}$ and Islamic law (penghancuran syari'ab). ${ }^{41}$ Additionally, they offer in some cases, significant and critical remarks to the ideas promoted by liberal Islam. In the case of religious freedom and pluralism, they argue that religious pluralism does not have foundation in Islamic teachings, and it obscures particular characteristics of religions. ${ }^{42}$ However, most of their critiques are on the basis of a normative perspective.

Alternatively, Nur Khalik Ridwan in his "'Mati' bagi Yang Berbeda: Menakar Fatwa Hukuman Mati Islam Radikal" ("Death" to Those Who are Different: Measuring Fatwa on the Death Penalty Issued by Radical Islam) ${ }^{43}$ supports, to some extent, the ideas of Ulil from a normative apologetic perspective. ${ }^{44} \mathrm{He}$ argues that Ulil has tried to provide a critical understanding of Islamic teachings, which need to be done in order to present Islam as a religion which can solve the problems faced by Muslims. He argues that Ulil is trying to create a new awareness amongst Indonesian Muslims and awaken from their long sleep. Nur Khalik also says that Ulil attempts to bring Islam downto-earth by introducing the historicity of Islam, including the historicity of the Prophet. This idea is similar to that of Anang Rizka Masyhadi (Anang) in his "Masih Tentang Ulil Abshar-Abdalla (Still on Ulil Abshar-Abdalla)". ${ }^{45}$

${ }^{39}$ See Ibid., pp. 106-110.

${ }^{40}$ Ibid., p. 83

${ }^{41}$ Ibid., p. 129.

${ }^{42}$ Ibid., p. 106.

${ }^{43}$ Nur Khalik Ridwan, “'Mati” Bagi Yang Berbeda: Menakar Fatwa Hukuman Mati Islam Radikal”, Journal Renai, Th. II. No. 3-4, 7 October 2002. This article is available in Islam Liberal \& Fundamental, pp. 39-68.

${ }^{44}$ Nur Khalik argues that the ideas introduced by Ulil concentrate on a conceptual level such as the historicity of the prophet, the law of God and do not pay much attention to the actual situations faced by Indonesian society such as the protection of labour, slavery of children and so forth.

${ }^{45}$ Anang Rizka Masyhadi, " Masih tentang Ulil Abshar-Abdalla," Duta Masyarakat, 17 Januari 2003. This article is also available in Islam Liberal \& Fundamental, pp. 96-99. 
Anang argues that the main sources of Islam, the Qur'an and the Hadith, are sacred, but this does not mean that the results of the interpretation of both sources becomes sacred. Interpretation is a result of understanding of both sources on the basis of a Muslim's creativity which is limited by context in time and place and, in some cases, the understanding may be in contradiction with the literal meaning of the text. To strengthen this argument, he refers to 'Umar ibn Khattab's ijtibäd on ghanima (the spoils of war) looted from the battle field in sawäd (Iraq). In this case, 'Umar did not distribute the ghanima (land) among the soldiers who were involved in the battle, as the Qur'an suggests he should have done, but maintained it as the property of the state and gave it back to the owners to cultivate. The owners were obliged to pay tax on the production from their land. 'Umar argued that if the land were distributed to the soldiers, later generations would not own it due to the land being divided among the solders. ${ }^{46}$

The case of "Umar from Anang's point of view is seen as an attempt to interpret the text based on the social context in which the text is applied. Connecting the text to the context provides a more fitting arrival at an understanding of the text than understanding based solely on the text. Using this method does not cast doubts on the validity of the Qur'an or Hadith. Given this analysis, it is acceptable to put the ideas of liberal Islam, including those articulated in Ulil's article, into this category.

\section{b. Critical Apologetic Response}

Unlike the normative apologetic response, which concentrates on the justification or rejection of the idea from a normative perspective, critical apologetic tries to do this by connecting the idea

${ }^{46}$ The case of ' $\mathrm{Umar}$ is often used to justify a critical understanding of the text in Islamic discourse made by substantialist Muslims. In the 1980s, Munawir Sadzali made the case as his foundation in offering the idea of Reaktualisasi Ajaran Islam regarding Islamic laws of inheritance. He argued that the idea was inspired by the case. See Munawir, Reaktualisasi Ajaran Islam, pp. 1-11. Ahmad Sahal, in one of his articles, also tries to track liberal Islam back to 'Umar period in which the creative understanding of Islam has deep roots. See Ahmad Sahal, "Umar bin Khattab dan Islam Liberal", in Luthfi, Wajah Liberal Islam, pp. 4-8. 
to the circumstances in which the idea exists. Such a critique can be seen in the work of Adnin Armas. In his "Pengarub Kristen-Orientalis terhadap Islam Liberal, Dialog Interaktif dengan Aktivis Jaringan Islam Liberal (Christian-Orientalist Impact to Liberal Islam, An Interactive Dialogue with the Activist of Jaringan Islam Liberal)", Adnin Armas (Adnin) argues that the ideas of liberal Islam have been heavily influenced by orientalist ideology which has a euro-centric bias. His critique concentrates on the idea of secularization and the historicity and the graduality of the text as promoted by JIL. ${ }^{47}$

Adnin is convinced the idea of secularization promoted by JIL is influenced by secularization in Christianity as upheld by Harvey Cox in his Secular City, which in turn has influenced Robert Bellah in his Beyond Belief. Through secularization, Cox has tried to build a bridge between conservative theologians, who believe on the truthfulness of the text (Bible) and who look upon the Bible (religion) as the best way of life, and radical theologians who insist on the radical reformation of the doctrines of Christianity because these doctrines are not suitable to finding solutions to real situations. In order to lessen the tension, Cox proposes the idea of secularization which tries to separate religion and mundane affairs. ${ }^{48}$ Furthermore, Adnin argues that in Indonesian Muslim society, the idea of secularization was adopted and promoted by Nurcholish Madjid in the 1970s and is currently continued by JIL. ${ }^{49}$

Commenting on the historicity and graduality of the text promoted by JIL, Adnin believes that their idea is influenced by the theory of evolution coined by Charles Darwin in his magnum opus: The Origin of Species, which says that all individuals will adjust to their environment. This theory has been adopted by sociologists to explain the development of religion within society. Herbert Spencer, Emile Durkheim, Auguste Comte, Max Weber, and Robert Bellah are some sociologists who have adopted the theory of evolution as a fundamental basis in their works. ${ }^{50}$

\footnotetext{
${ }^{47}$ Adnin Armas, Pengarub Kristen Orientalis, pp. 1-30; 103-116.

${ }^{48}$ Ibid., p. 7.

${ }^{49}$ Ibid., p. 14.

${ }^{50}$ Ibid., pp. 106-108.
} 
Whilst Adnin tends to negatively comment on liberal Islam, Hamid Basyaib (Hamid) in his "Menyegarkan Pemahaman Islam: Sebuah Afirmasi” (Freshening Understanding Islam: An Affirmation) ${ }^{51}$ can be said to offer a critical apologetic response which contains some positive remarks about JIL (Hamid himself is a proponent of JIL). According to Hamid, the core of Ulil's ideas is that Islamic teaching, as mentioned in the Qur'an and the Hadith, should be continually reinterpreted in line with the social context. This does not mean that the teaching is opportunistically synchronized with the context, but that particular contexts within which the text are applied, should be taken into consideration. These values must be considered in interpretation in order for interpretation to solve the problems faced by Muslims.

\section{c) Practical Apologetic Response}

A fatwa on the death penalty has been delivered by a group of Muslims who have unified themselves into the FUUI (Forum Ulama Umat Islam/Forum of Islamic Religious Scholars of the Muslim Community) in response to "Menyegarkan Kembali Pemahaman Islam". As was reported by Tempo 22 December 2002, not so long after the article was published, some eighty Muslims from East, Central and West Java, coordinated by Athian Ali, had a meeting in a mosque (alFajr), Bandung to discuss some important issues in Indonesia such as the capture of the chairperson of the Majelis Mujabidin Indonesia, Abu Bakar Ba'asyir, anti-terrorist regulation and Ulil's article. Dissecting the article, the forum argued that the ideas promoted by Ulil can be classified as a humiliation to Islam.

The forum then publicly issued a four-point collective statement on 2 December 2002. The third point of the four deals with the humiliation of Islam, whereby the forum insisted on the death penalty for those who humiliate Islam, and insists on the police breaking up any activity which systematically and massively humiliates Islam, Allah

${ }^{51}$ Hamid Basyaib, "Menyegarkan Pemahaman Islam: Sebuah Afirmasi,” Panjimas, 27 December 2002. This article is also available in Islam Liberal \& Fundamental, pp. 29-35. 
and the Prophet Muhammad. ${ }^{52}$ At the end of the statement, the forum argued that in accordance with Islamic teachings, any people who distort Islamic teachings should be punished by the imposition of the death penalty. ${ }^{53}$

Although the coordinator, Athian Ali rejected the claim that the fatwa $\bar{a}$ was specifically devoted to the case of Ulil, ${ }^{54}$ there has been a very recent case in which the issuance of the death penalty fatw $\bar{a}$ was related to Ulil's article. This is strengthened by Athian's statement which has been quoted by Adnan Firdaus in his "Fatwa Mati buat yang "Usil" (Death Penalty for Annoying People). In this article, Adnan Firdaus quotes Athian's statement saying that Ulil's article is part of attempt to humiliate Islam by humiliating Allah and His Messenger. He finishes the argument, indicating that the ulama are a group of stupid people who have been frustrated in their attempt to solve contemporary problems by implementation of shari ${ }^{6} a^{55}$

\section{3) Technical Response}

The technical response is a response concentrating on the way the JIL communicates with its audience. In this case, the central point of the response is the technical method by which JIL promotes its ideas. Responses that concentrate on criticizing Ulil's technique include

52 “Fatwa Itu Lemah Tapi Menghawatirkan, Tempo, No. 42, 22 December 2002. This report is available in Islam Liberal \& Fundamental, pp. 207-216.

${ }^{53}$ Ibid.

54 “Terlalu kecil jika kami mengurusi dia" (It is too trivial for us to handle it [his article]).

55 “....Kami menyerukan kepada pemerintah untuk membongkar jaringan yang selama ini menurut kami telah menghujat Islam. Di antaranya, tulisan Ulil Abshar-Abdalla itu. Di situ, dia telah menghina Allah, menghina rasulullah, dan menganggap para ulama yang memperjuangkan Syari 'at Islam sebagai manusia-manusia picik. yang kehabisan akal, frustrasi, dan mencoba mencari jalan keluar hanya dengan kembali ingin menjalankan hukum Allah." [We appeal to the government to break up a network which blasphemes against Islam according to us. The article written by Ulil Abshar-Abdalla is an example. In this article, he humiliates Allah, the Prophet, and accuses that 'Ulama who struggle for the implementation of shari' $a$ of being narrow minded and frustrated persons who try to solve the problems by going back to the implementation of law of God]. See M. Adnan Firdaus, "Fatwa Mati Buat Yang "Usil"," Sabili, No. 12 Th. 10, December 2002. This article is available in Islam Liberal \& Fundamental, pp. 191-192. 
"Menyegarkan Kembali Sikap Islam" (Freshening up Islamic Attitudes $)^{56}$ by Mustofa Bisri and, to some extent the article "Memahami Kontroversi Tulisan Ulil Abshar-Abdalla"(Understanding The Controversy of Ulil Abshar-Abdalla) by Ratno Lukito. ${ }^{57}$

Mustofa Bisri criticizes the way in which Ulil Abshar-Abdalla communicates the ideas of liberal Islam to his audience. He accuses Ulil of making mistakes by firstly putting forward his ideas in the form of highly charged expressions which are hostile towards Islamic fundamentalism and also comments that Ulil does not use less hostile methods of communication in general. Secondly, he attacks the media through which Ulil chooses to disseminate his ideas. He feels that the publication of ideas through a daily newspaper, Kompas, which all people can read easily is improper. As a result, the people which the article is not addressing are confused. According to Mustofa Bisri, such articles should be publicized to a limited group of people, read only by audience to whom the article addresses.

On the other hand, Ratno Lukito, although he does not agree with the way Ulil chooses to express his ideas, tolerates the method of communication by which Ulil promoted his article. Ratno acknowledges it is true that Ulil wrote the article to give full vent to his emotion. But, although it displays the typical expressions of a young person, it does not detract from the matters which Ulil raises. At the end of his article, Ratno Lukito argues that Ulil's article should be seen as a part of the development of Islamic thought in contemporary Indonesia. It should be kept in mind that Ulil successfully expresses contemporary Islamic thought. What Indonesian Muslims should do is to direct the

\footnotetext{
${ }^{56}$ Mustofa Bisri, "Menyegarkan Kembali Sikap Islam,” Kompas, 5 December 2002.

${ }^{57}$ Ratno Lukito, "Memahami Kontroversi Tulisan Ulil Abshar-Abdalla," Kompas, 13 December 2002. In this article, he also pays much attention to the way of thinking by which Ulil introduces the ideas. Inspired by the concept of conflict and tension of Noel Coulson which states that there are some conflicts and tensions in Islam like the particular and the universal, the sacred and the profane, continuity and change, unity and diversity and so forth, Ratno argues that Ulil tries to show that Islam consists of sacred and profane values (secularization) and shows that Islamic teachings, in some places have the potential to be reinterpreted.
} 
conflict of Islamic thought into a channel of healthy discourse which will benefit the movement of Islam.

\section{Responses as Questions on Validity}

Various responses devoted to JIL indicate that it has some problems with its authority: methodology, ideas, and methods of communication. Firstly, methodological responses are ones which try to question the validity of the method by which the ideas have been formulated and question the authority of JIL to promote the ideas. It only proposes the idea of critical understanding of Islamic teachings, but does not formulate the technical method which should be applied to understand Islamic teachings. The lack of this method gives a negative impression that JIL only arbitrarily understands Islamic teachings. An example, where the basis of the argument was never clearly formulated, was the case of jilbāb as has been criticized by Haidar Bagir, whereby JIL argues that wearing a jilbäb is not compulsory for Muslim women.

Secondly, as a result of using an inadequate method, the ideas that JIL promotes are weakly formulated. Although some Muslims believe that the themes which become main ideas of liberal Islam can be traced back to Islamic teachings through a critical understanding of Islam, some argue that the ideas of liberal Islam like secularization, religious freedom and pluralism do not have a normative foundation in Islam. These ideas are taken from outside and were arbitrarily claimed by liberal Muslims to be part of Islamic teachings.

Thirdly, technical responses can be seen which question the ability of the proponents of JIL to communicate its ideas to Indonesian Muslims as the audience. To some extent, the response devoted by Mustofa Bisri indicates that the members of JIL do not pay much attention to this aspect. The result is that there is an impression that its members are arrogant in the dissemination of their ideas.

Various responses devoted to JIL are a repetition of the various responses addressed to Renewal of Islamic Thought in the early 1970s. Basically, it can be claimed that most of the proponents of the idea of pembaharuan were young educated Muslims at that time. They have argued that Renewal of Islamic Thought was a positive contribution 
to Islam because it promoted a critical interpretation of Islamic teachings by searching the essential meaning of the text (maqāsid alshari' $^{-} a$ ) which can only be found by analysing the meanings beyond the text. ${ }^{58}$ Islam has been interpreted as a flexible religion which is inconformity with modernity and propagates this idea to Muslims in Indonesia. ${ }^{59}$ It has offered a new way of understanding Islam, and thus gave indirect support to the idea of pluralism, ${ }^{60}$ and an attempt to present the friendly face of Islam. ${ }^{61}$ It is also described as an attempt to place the profile of Islam on an academic and philosophical level which reveals the real nature of Islam and insists on the universality of Islamic spirituality. ${ }^{62}$

Various methodological responses have also been devoted to Renewal of Islamic Thought. Critiques by Amin Abdullah, Ahmad Baso and the emergence of Islam Transformation were similar to the methodological responses devoted to JIL.

Amin Abdullah criticized the method by which the idea of pembaharuan was promoted. Renewal of Islamic Thought has focused on general social problems by using a sociological and historical approach, but has paid less attention to the local values and the psychological nature of Indonesian Muslims. The anthropological approach, which insists on local values and specific character of human being, and the psychological approach, which focuses on the emotional attitude of human beings, did not play a significant role in this matter. This situation has led to Renewal of Islamic Thought's unacceptability by some groups of Muslims. ${ }^{63}$

Ahmad Baso criticized the precedents to which the ideas of Renewal of Islamic Thought refer. They were a group trying to revive

${ }^{58}$ Fachri Ali and Bahtiar Effendi, Merambah Jalan Baru Islam Rekonstruksi Pemikiran Islam Indonesia Masa Orde Baru (Bandung: Mizan, 1986), pp. 34-35.

${ }^{59}$ Fauzan Shaleh, Modern Trends, p. 196.

${ }^{60}$ Ibid.

${ }^{61}$ Mohamad Sobary, “Jalan Arteri ke Rumah Tuhan” Ulumul Qur'an, Jurnal Ilmu dan Kebudayaan, No. 1. Vol. IV Tahun 1993, pp. 26-27.

${ }^{62}$ Masdar F. Mas'udi, "Ide Pembaharuan Cak Nur di Mata Orang Pesantren" Ulumul Qur'an, Vol. 1. Vol. IV, pp. 28-33.

${ }^{63}$ M. Amin Abdullah, "Islam Indonesia lebih Pluralistik dan Demokratis," Ulumul Qur'an, No. 3. Vol. VI Tahun 1995, pp. 72-73. 
the past in the present by justifying the ideas of democratisation, pluralism and tolerance as ideas which had been put into practice during the period of the Prophet and his Rightly-Guided Caliphs. ${ }^{64}$ In fact, the early Muslim community did not reflect the real values of egalitarianism or the idea of tolerance upheld by Nurcholish Madjid. This was indicated by non-Muslims being considered second-class citizens in the society. ${ }^{65}$

Islam Transformasi (transformation Islam) is another response to the ideas of Renewal of Islamic Thought. This critique concentrates on the idea and the method by which Renewal of Islamic Thought was upheld. Islam Transformasi argued that Renewal of Islamic Thought was highly coloured by the theological method which focuses on the religious attitudes of Indonesian Muslims, and paid less attention to the societal problems caused by social relationship. Islam Transformatif proposed a dialectical method combining a theological and a social approach. The theological method is to observe the theological problem of the backwardness of Muslims and the social method is to solve social problems which Muslims face. The backwardness of Indonesian Muslims is not only because of their adoption of an incorrect theology and cultural attitudes, but it is also because of unequal relationships within society, namely between the higher classes and the lower classes and, in a wider sense, between developed and developing countries.

${ }^{64}$ Ahmad Baso, Civil Society versus Masyarakat Madani, (Yogyakarta, LKiS), pp. 272-273. To verify these ideas, Nurcholish Madjid refers to the works of Ibn Taymiyya, Marshal Hodgson, Ernest Gellner and Max Dimont. According to Fauzan Saleh, in these works, Islam is described as a religion adopting all of the idea of democratisation, pluralism and tolerance. See Fauzan Shaleh, Modern Trends, p. 286.

${ }^{65}$ According to Ahmad Baso as noted by Fauzan Saleh, Nurcholish Madjid's uncritical acceptance of the Islamic historical past is also because of his unfamiliarity with the works of contemporary Muslim scholars, like Muhammad Arkoun, Hassan Hanafi, Muhammad Abed al-Jabiri, and Nasr Hamid Abu Zaid. See, Ibid., p. 287. But it should be kept in mind that the idea of Renewal of Islamic Thought promoted by Nurcholish Madjid was started at the early 1970s, while the works of those people mentioned above were widely known since the 1980s and 1990s. Mafbum al-Nas of Abu Zaid, for example, was published in early 1993. So it is an anachronistic critique if criticizing Nurcholish Madjid's mode of thought from the side of his unfamiliarity to the works of contemporary Muslim scholars. 
The higher classes position themselves as superior and exploit the lower. ${ }^{66}$ There is no equality and justice in society.

Creating a new social order, then, is the solution, a social order which will provide the opportunity for equality and justice among its members. The solution to backwardness should be based, not only on the internal problems faced by Muslims such as the idea of Renewal of Islamic Thought, but should also be founded on the reality of Indonesian society and general concerns of Indonesian society such as with education and culture. ${ }^{67}$

Other critiques by some Muslims like Endang Saefuddin Anshari ${ }^{68}$ Ismail Hasan Metareuem, ${ }^{69}$ H.M. Rasjidi, ${ }^{70}$ Abdul Qadir Djailani, ${ }^{71}$ and critiques by Media Dakwah as well, ${ }^{72}$ were also similar to the apologetic responses devoted to JIL. Media Dakwah and Abdul Qadir Djailani who reject the ideas of Renewal of Islamic Thought as odd ideas and who consider its proponents to be agents of the political movement and global strategy of Zionism, which tries to dominate the world, can be categorized as apologetic responses. They argued that the idea of Renewal of Islamic Thought was not relevant to the needs of Indonesian Muslims, and contradicted the spirit of ukhumwa Islamiyya (Muslim brotherhood) the most important concern for a plural

${ }^{66}$ Budhy Munawar-Rahman, "Berbagai Respon”, p. 22.

${ }^{67}$ Ibid., p. 23.

${ }^{68}$ Endang Saifuddin Anshari, Kritik atas Faham dan Gerakan "Pembaharuan" Drs. Nurcholish Madjid, (Bandung: Bulan Sabit, 1973).

${ }^{69}$ Ismail Hasan Metareuem, "Pembahasan terhadap Prasaran Sdr. Drs. Nurcholish Madjid: tentang Keharusan Pembaharuan Pemikiran Islam dan Masalah Integrasi Ummat," in Nurcholish Madjid et al., Pembaharuan Pemikiran Islam, (Jakarta: Islamic Research Centre, 1970), pp. 26-38.

${ }^{70}$ H.M. Rasjidi, Koreksi terhadap Drs. Nurcholish Madjid tentang Sekularisasi, (Jakarta: Bulan Bintang, 1972).

${ }^{71}$ Abdul Qadir Djailani, Menelusuri Kekeliruan Pembaharuan Islam Nurcholish Madjid, (Bandung: Yadia, 1994). Fauzan Saleh in his Modern Trends classifies Abdul Qadir Djailani as a proponent of scripturalism. See, Fauzan Saleh, Modern Trends, p. 184.

${ }^{72}$ Media Dakwah is a weekly magazine published by DDII (Dewan Dakwah Islamiyah Indonesia/The Indonesian Council of Islamic Missions), an institution which energetically propagates Islamic teachings in Indonesia. 
society like Indonesia. ${ }^{73}$ Abdul Qadir Djailani, even, argued that Nurcholish Madjid has consciously tried to break up the integration of Indonesian Muslim society and to make Indonesian Muslims confused. ${ }^{74}$

The technical response is another response which can be found in the responses devoted to Renewal of Islamic Thought. Renewal of Islamic Thought was criticized as a movement of the middle class which can only be understood by well-educated people.

Practical apologetic responses are responses which differentiate between those devoted to Renewal of Islamic Thought and JIL. It is correct that such responses can be seen with the harsh objection by Media Dakwah to Nurcholish Madjid, who was condemned as a person who should be brought to justice by the community, and a cancer which must be removed from the body of Islam. ${ }^{75}$ But these attacks were only polemical in nature. None of the responses leads to the direct threat of the physical punishment like the fatwa of a death penalty issued by FUUI to Ulil Abshar-Abdalla.

Apart from the discussion above, some criticisms can be addressed to JIL. As a disseminator of liberal Islam, JIL tends to be framed as an extreme group. If Islamic fundamentalism claims that literal meaning is the only authoritative interpretation, JIL falls into the opposite side whereby the most important authority is the meaning beyond the text. While fundamentalist Islam has the potential to fall into an anachronistic interpretation because of the application of the text without considering the context, liberal Islam has the potential to fall into a pragmatic one because many interpretations can be found for the one situation. In this case, the way of thinking plays a significant

${ }^{73}$ See, H.M. Rasjidi, Koreksi Terbadap Drs Nurcholish Madjid Tentang Sekularisasi, (Jakarta: Bulan Bintang, 1972); Idem, Suatu Koreksi Lagi bagi Drs Nurcholish Madjid, (Banjarmasin: Dewan Da'wah Islamiyah Indonesia Perwakilan Kalimantan Selatan, 1973); Endang Saefuddin Anshari, Kritik atas Faham dan Gerakan Pembaharuan Drs Nurcholish Madjid, (Bandung: Bulan Sabit, 1973); Abdul Qadir Djaelani, Menelusuri Kekeliruan Pembaharuan Pemikiran Islam Nurcholish Madijd, (Bandung: Yadia, 1994).

${ }^{74}$ Abdul Qadir Djailani, Menelusuri Kekeliruan, p. 22.

${ }^{75}$ See William Liddle, "Media Dakwah Scripturalism: One Form of Islamic Political thought and Action in New Order Indonesia" in Mark R. Woodward (ed.), Toward a New Paradigm: Recent Developments in Indonesian Islamic Thought, (Temple, Arizona: Arizona State University, 1996), p. 327. 
role. If no adequate method can be formulated for the interpretation, it is a concern that an incorrect practice will be justified in the name of Islam. In Haidar Bagir's term, Islam will be a "keranjang sampab”(rubbish tank) into which all things can be put. ${ }^{76}$

"Package from the sponsor" is probably a phrase to describe the dependency of JIL to funding. The dependency on western funding makes it difficult for JIL to escape from a western bias. It is still in doubt that such terms as democratization, pluralism, religious freedom and human rights are self-consciousnessly Indonesian as these terms remain peculiar among Indonesian Muslims. Rather, they are western ideas which have been introduced to Indonesia. It is possible to implement these ideas, but they should be reformulated in order to be in conformity with Indonesian society. In this context, the particular values and experiences of Indonesian Muslim society plays significant role.

Another critique is that JIL is an elitist institution. Like Renewal of Islamic Thought, it is a representation of the middle class through the eyes of some young scholars. For the majority of Indonesian Muslims, the ideas which JIL promotes are very complicated ones and can only be understood by well-educated people. Thus JIL is perceived to be only an agent of thinking, which can only promote ideas on a conceptual level. It is not able to correlate its ideas with real problems faced by the Indonesian society, or in Umaruddin's term it fosters: keberagamaan berbasis ilusi (illusion-based religiousness). ${ }^{77}$ As a result, the ideas upheld by JIL are not pragmatic and do not meet the needs of Indonesian Muslims. So it is quite easy for some Muslims, who disagree with JIL, to object and even condemn JIL as a presentation of the inferiority of Muslims before the West. ${ }^{78}$

\footnotetext{
${ }^{76}$ Haidar Bagir, "Islib Butuh Metodologi,” Republika 23 March 2003.

${ }^{77}$ Umaruddin Masdar, Agama Kolonial.

${ }^{78}$ Media Dakwah, as has been quoted by Akh. Muzakki condemns the JIL as a terror to Islam, as a diabolical logic (logika iblis), as a deviant sect, as an agent of orientalists and secularists. See Akh. Muzakki, "Perseteruan Dua Kutub, p. 43.
} 


\section{E. Conclusion}

Jaringan Islam Liberal, as an agent of the liberal Islam movement in Indonesia, has been responded to in various forms. Fundamentalist Islam, as an opponent of liberal Islam, harshly rejects JIL's ideas. It believes that liberal Islam propagated by JIL does not have a normative foundation in Islam. In the case of religious freedom and pluralism, it argues that both ideas are in conflict with Islamic doctrines and the early period of the history of Islam. This rejection is based on the different ideologies and methods of thinking used by both groups. While JIL promotes an inclusive ideology and a non-literal interpretation of the text, fundamentalist Islam propagates an exclusive ideology and a literal interpretation of the text.

Other Indonesian Muslims have given various responses to liberal Islam. These responses are generally classified into three categories. The first is a methodological critical response which tries to criticize the methodological approach used by JIL to promote its ideas. The second is an apologetic response which focuses on the validity of ideas which JIL promotes. Three forms of responses can be derived from the apologetic response: firstly, a normative apologetic response focusing on the normative doctrines in which the idea of liberal Islam is based; secondly, a critical apologetic response which tries to connect the idea of liberal Islam to the circumstance in which the idea is formed and applied; thirdly, a practical apologetic response. This response leads to the prosecution of physical action. The third is the technical response which relates to the way JIL communicates its ideas to its audience (Indonesian Muslims).

Various responses devoted to JIL are a repetition of the various responses addressed to renewal of Islamic thought in the early 1970s. Practical apologetic responses are the point of difference between the responses devoted to renewal of Islamic thought and JIL. This type of response cannot be found in the responses which are objected to renewal of Islamic thought. 


\section{BIBLIOGRAPHY}

"Fatwa Itu Lemah Tapi Menghawatirkan, Tempo, No. 42, 22 December 2002.

"Islam Liberal Versus Islam Literal," Tempo, No. 38/XXX(19-25 November 2001).

Abdul Qadir Djaelani, Menelusuri Kekeliruan Pembaharuan Pemikiran Islam Nurcholish Madijd, Bandung: Yadia, 1994.

Adian Husaini and Nuim Hidayat, Islam Liberal: Sejarah, Konsepsi, Penyimpangan dan Jawabannya, Jakarta: Gema Insani Press, 2002.

Adnin Armas, Pengarub Kristen-Orientalis terbadap Islam Liberal, Dialog Interaktif dengan Aktivis Jaringan Islam Liberal, Jakarta: Gema Insani Press, 2003.

Ahmad Baso, Civil Society versus Masyarakat Madani, Yogyakarta, LKiS, 1998.

Ahmad Gaus AF, "How Liberal Can You Go?," Kompas, 13 December 2002.

Ahmad Sahal, "Umar bin Khattab dan Islam Liberal”, in Luthfi, Wajah Islam Liberal di Indonesia, Jakarta: Jaringan Islam Liberal, 2002, p. $4-8$

Akh. Muzakki, "Perseteruan Dua Kutub Pemikiran Islam Indonesia Kontemporer: Jaringan Islam Liberal dan Media Dakwah," Jurnal Universitas Paramadina Vol. 3 No. 1, September 2003, pp. 40-62.

Anang Rizka Masyhadi, "Masih tentang Ulil Abshar-Abdalla," Duta Masyarakat, 17 Januari 2003.

Binder, Leonard, Islamic Liberalism: A Critique of Development Ideologies, Chicago: University of Chicago Press, 1988.

Budhy Munawar-Rahman, "Berbagai Respon atas Gagasan Pembaharuan” Ulumul Qur'an Vol. 1 No. IV, Tahun 1993.

Endang Saefuddin Anshari, Kritik atas Faham dan Gerakan Pembaharuan Drs. Nurcholish Madjid, Bandung: Bulan Sabit, 1973.

Fachri Ali and Bahtiar Effendi, Merambah Jalan Baru Islam Rekonstruksi Pemikiran Islam Indonesia Masa Orde Baru, Bandung: Mizan, 1986. 
Fauzan Saleh, Modern Trends in Islamic Theological Discourse in $20^{\text {th }}$ Century Indonesia, A Critical Survey, Leiden-Boston-Koln: Brill, 2001.

H.M. Rasjidi, Koreksi Terhadap Drs Nurcholish Madjid Tentang Sekularisasi, Jakarta: Bulan Bintang, 1972.

----, Suatu Koreksi Lagi bagi Drs Nurcholish Madjid, Banjarmasin: Dewan Da'wah Islamiyah Indonesia Perwakilan Kalimantan Selatan, 1973. Haidar Bagir, "Beberapa Pertanyaan untuk Ulil Abshar-Abdalla", Kompas, 5 December 2002.

----, “Islib Butuh Metodologi” Republika, Selasa 20 Maret 2002.

Hamid Basyaib, "Islib Butuh Methodology? (Tanggapan untuk Haidar Bagir)," Republika, 23 March 2002.

----, "Menyegarkan Pemahaman Islam: Sebuah Afirmasi," Panjimas, 27 December 2002.

Hartono Ahmad Jaiz, Bahaya Islam Liberal, Jakarta: Pustaka al-Kautsar, 2002.

Husni Mu'adz, "Komentar Serius Untuk Ulil Abshar-Abdalla, www.media.isnet.org/islam., accessed on 7 October 2003.

Ismail Hasan Metareuem, "Pembahasan terhadap Prasaran Sdr. Drs. Nurcholish Madjid: tentang Keharusan Pembaharuan Pemikiran Islam dan Masalah Integrasi Ummat," in Nurcholish Madjid et al., Pembaharuan Pemikiran Islam, Jakarta: Islamic Research Centre, 1970, pp. 26-38.

Liddle, William, "Media Dakwah Scripturalism: One Form of Islamic Political thought and Action in New Order Indonesia" in Mark R. Woodward (ed.), Toward a New Paradigm: Recent Developments in Indonesian Islamic Thought, Temple, Arizona: Arizona State University, 1996, p. 327.

M. Adnan Firdaus, "Fatwa Mati Buat Yang "Usil”," Sabili, No. 12 Th. 10, December 2002.

M. Amin Abdullah, "Islam Indonesia lebih Pluralistik dan Demokratis," Ulumul Qur'an, No. 3. Vol. VI Tahun 1995, pp. 72-73.

Masdar F. Mas'udi, "Ide Pembaharuan Cak Nur di Mata Orang Pesantren” Ulumul Qur'an, Vol. 1. Vol. IV, pp. 28-33. 
Mohamad Sobary, “Jalan Arteri ke Rumah Tuhan” Ulumul Qur'an, Jurnal Ilmu dan Kebudayaan, No. 1. Vol. IV Tahun 1993, pp. 26-27.

Mustofa Bisri, "Menyegarkan Kembali Sikap Islam," Kompas, 5 December 2002.

Nur Khalik Ridwan, “'Mati” Bagi Yang Berbeda: Menakar Fatwa Hukuman Mati Islam Radikal", Journal Renai, Th. II. No. 3-4, 7 October 2002.

Ratno Lukito, "Memahami Kontroversi Tulisan Ulil Abshar-Abdalla," Kompas, 13 December 2002.

Salahuddin Wahid, “JIL Lebih Liberal dari Cak Nur”, Sabili No. 15 Th. IX 25 January 2002, p. 90.

Ulil Abshar-Abdalla et al., Islam Liberal \& Fundamental, Sebuah Pertarungan Wacana, Yogyakarta: eLSAQ, 2003.

---, "Menyegarkan Kembali Pemahaman Islam," Kompas, 18 November 2002.

Umaruddin Masdar, Agama Kolonial, Colonial Mindset dalam Pemikiran Islam Liberal, Yogyakarta: Klik.R, 2003. 